\title{
REENTRY REFORM IN INDIANA: HEA 1006 AND ITS (MUCH TOO NARROW) FOCUS ON PRISON OVERCROWDING
}

\author{
DREW KIRAGES*
}

\section{INTRODUCTION}

Dealing with rising prison populations is a major component of criminal justice reform. ${ }^{1}$ One reason for this is the enormous construction costs for new correctional facilities. ${ }^{2}$ In 2002, the Federal Bureau of Prisons budgeted nearly $\$ 1.6$ billion for the construction of thirteen new prison facilities. ${ }^{3}$ Yet, the projects were estimated to add merely 15,000 beds to the facilities' operational bed capacities: once finished, it will have cost over $\$ 100,000$ for every bed added. ${ }^{4}$ Likewise, there were estimates that Indiana would have to spend $\$ 1.2$ billion to expand its facilities if steps were not taken to reduce the prison population. ${ }^{5}$

Cost savings is a politically advantageous goal; states have been keen on operating with a balanced budget. ${ }^{6}$ In fact, all of the states except Vermont have a constitutional or statutory mandate to balance the state budget. ${ }^{7}$ Indiana was one of the first states to adopt such a requirement back in $1851^{8}$ and one of the first

* J.D. Candidate, 2016, Indiana University Robert H. McKinney School of Law; B.A., 2013, Ball State University, Muncie, Indiana. I would like to thank my wife Lauren, my friends, and my family for their love and support. Thank you to Madonna Wagoner, Ralph Watson, Jason Sloderbeck, and Megan Grasso for their willingness to be interviewed for this Note. Finally, a special thanks goes to Professor Lahny Silva for helping me realize my potential and assisting throughout the entire Note-writing process.

1. Press Release, Dep't of Justice, One Year after Launching Key Sentencing Reforms, Attorney General Holder Announces First Drop in Federal Prison Population in More Than Three Decades (Sept. 23, 2014), available at http://www.justice.gov/opa/pr/one-year-after-launching-keysetencing-reforms-attorney-general-holder-annouces-first-drop-0 [http://perma.cc/4CKM-LUZ6].

2. $I d$.

3. Fed. Bureau of Prisons, Management of Construction Contracts 2 (2002), http://www.justice.gov/oig/reports/BOP/a0232/final.pdf [http://perma.cc/35M5-S9Y4].

4. Id. Operational bed capacity does not always refer to the actual number of beds available for use. Classifying prisoners by security risk or special needs may leave some portions of prison facilities dormant. Interview with Capt. Jason Sloderbeck, Jail Commander, Hamilton Cnty. Sheriff's Dept., in Noblesville, Ind. (Oct. 21, 2014) [hereinafter Sloderbeck Interview].

5. Justice Reinvestment in Indiana, Council of State Gov'ts Justice CTR., http://csgjusticecenter.org/jr/in/ [http://perma.cc/9FQR-4F9X] (last visited Oct. 9, 2014).

6. Nat'l Conference of State Legislators, NCSL Fiscal Brief: State Balanced Budget PREVIEw 1 (2010), available at http://www.ncsl.org/documents/fiscal/statebalancedbudget provisions2010.pdf [http://perma.cc/G5S9-2S2J].

7. $I d$. at 2 .

8. Michael Powell \& Monica Davey, The Indiana Exception? Yes, but..., N.Y. TimES, June 23, 2011, at A12, available at http://www.nytimes.com/2011/06/23/us/23indiana.html?page wanted=all\&_r=0 [http://perma.cc/A9NY-9Z8A]. 
three states to record over a one billion dollar budget surplus in fiscal year 2014. ${ }^{9}$ During his 2015 State of the State address, Indiana Governor Mike Pence called on the General Assembly to pass a new constitutional balanced-budget amendment. ${ }^{10}$ However, reducing spending on prison construction and expansion is not as simple as merely reducing prison populations. ${ }^{11}$

According to Megan Grasso of the Council of State Governments Justice Center, reducing prison populations and reducing recidivism are two goals that cannot be separated:

Through reducing recidivism, fewer people reoffend and return to prison, which helps reduce prison crowding. However, simply reducing prison populations without regard to reducing recidivism is unlikely to achieve long-term success if people released into the community continue to reoffend and reenter prison. Therefore, to be successful with either goal, both issues must be addressed. ${ }^{12}$

Not only are reducing recidivism and prison overcrowding two goals that cannot be separated, both are inextricably linked from the politically-advantageous goal of lowering criminal justice costs for state taxpayers. ${ }^{13}$

Recidivism is defined by the Indiana Department of Correction ("IDOC") as "a return to incarceration within three years of the offender's date of release from a state correctional institution." ${ }^{\prime 4}$ Over one in three inmates in the IDOC fits the state's definition of a recidivating offender. ${ }^{15}$ This figure does not account for recidivating county jail inmates or those who reoffend after a stint on probation or another community corrections program, ${ }^{16}$ such as work release or electronic home monitoring. ${ }^{17}$ For simplicity's sake, when this Note refers to the IDOC it

9. Reid Wilson, After Years of Cuts, State Budgets Show Surpluses, WASH. Post (July 15, 2014), http://www.washingtonpost.com/blogs/govbeat/wp/2014/07/15/after-years-of-cuts-statebudgets-show-surpluses/ [http://perma.cc/JW6X-M68S] (the other two states are Arkansas and Georgia).

10. Press Release, Indiana Governor Mike Pence, 2015 State of the State Address (Jan. 13, 2015), available at http://www.in.gov/gov/2015stateofstate.htm [http://perma.cc/4BYG-DJUD].

11. E-mail Interview with Megan Grasso, Publications Editor, Council of State Governments Justice Center (Sep. 25, 2014) (transcript on file with author) [hereinafter Grasso E-mail Interview].

12. Id.

13. See generally Brandon C. Welsh \& David P. Farrington, Monetary Costs and Benefits of Crime Prevention Programs, 27 CRIME \& JUST. 305 (2000).

14. IND. DEP'T OF CORR., 2013 RECIDIVISM SUMMARY (2013), available at http://www.in. gov/idoc/2376.htm [http://perma.cc/GP4-WEMC] [hereinafter 2013 RECIDIVISM SUMMARY].

15. $I d$.

16. These programs include work release, home detention/electronic monitoring, day reporting, juvenile alternatives, work crew/community service, and adult services. IND. DEP'T OF Corr., Community Corrections Fiscal Breakdown for Fiscal Year 2013 (2013) (on file with author); see generally Community Corrections, IND. DEP'T OFCORR., http://www.in.gov/idoc/ 2320.htm [http://perma.cc/EYB6-GTVL] (last visited Oct. 10, 2014).

17. 2013 RECIDIVISM SUMMARY, supra note 14. 
is referring to all of the state prison facilities collectively.

One major way to reduce recidivism and increase cost savings is through reentry-oriented reform, i.e., instituting "pre-release readiness [programs], reintegration training, job preparedness[,] . . discharge planning" and other like programming to prepare individuals leaving prison to reenter the community. ${ }^{18}$ Reentry-oriented reform began in the late 1990s, beginning what criminal justice scholar Jeremy Travis called a "major new development in American criminal justice policy." 19 The reliance on reentry policies to help reduce recidivism is justified by the massive amount of prisoners reentering American communities every year: in 2002, nearly 600,000 state prison inmates were released from U.S. prisons and jails. ${ }^{20}$ Recent criminal justice reform efforts have primarily focused on reentry policies due in large part to this extremely high number of individuals leaving prison on a yearly basis. ${ }^{21}$

Reentry policies are both numerous and effective ${ }^{22}$ and states have not only reduced their prison populations, which saves taxpayers from costly construction projects, but states have also concurrently reduced their recidivism rates. ${ }^{23}$ For example, in 2012, Georgia instituted criminal justice reentry reform that focused on the rehabilitation of non-violent offenders and exploring alternatives to prison, including "community supervision and programs and services focused on addressing reentry needs." ${ }^{24}$ Experts estimate that Georgia's prison population will decrease by 5000 inmates by 2017 , saving the state upwards of $\$ 260$ million. ${ }^{25}$ Another example comes from Texas, whose prison population was projected to grow by 14,000 inmates between 2007 and $2012 .{ }^{26}$ In light of those projections, Texas instituted justice-reinvestment policies, adopting an "approach that uses data driven, fiscally responsible policies and practices to increase public

18. Reginald A. Wilkinson et al., Prison Reform Through Offender Reentry: A Partnership between Courts and Corrections, 24 PACE L. REV. 609, 611 (2004).

19. Jeremy Travis, Reflections on the Reentry Movement, 20 FED. SENT'G REP. 84, 84 (2007).

20. U.S.DeP't of Justice, Bureau of Justice Statistics, ReEnTRY TRENDS IN THE United STATES 7 (2002), http://www.bjs.gov/content/pub/pdf/reentry.pdf [http://perma.cc/9SN-MELK].

21. Michael Pinard, A Reentry-Centered Vision of Criminal Justice, 20FED. SENT'G REP. 103, 103 (2007).

22. See Council of State Gov'ts Justice Ctr., Reducing Recidivism: States Deliver RESULTS (2014), available at http://csgjusticecenter.org/wp-content/uploads/2014/06/Reducing Recidivism_StatesDeliverResults.pdf [http://perma.cc/7MNP-8NBB] [hereinafter CouNCIL OF StATE GOv' Ts JustiCE CTR., REDUCING RECIDIVISM] (outlining eight states that effectively reduced recidivism rates through certain reentry-oriented policies); see generally Travis, supra note 19.

23. Grasso E-mail Interview, supra note 11.

24. Council of State Gov'ts Justice Ctr., Reducing Recidivism, supra note 22.

25. $I d$.

26. Press Release, Council of State Gov'ts Justice Ctr., Congressional Leaders Take on Recidivism and Corrections Spending (Jan. 28, 2010), available at http://csgjusticecenter.org/wpcontent/uploads/2012/11/National_Justice_Reinvestment_Summit_Press_Release.pdf [http://perma.cc/PK33-ZJYC] [hereinafter Press Release, Council of State Gov'ts Justice Ctr.]. 
safety and reduce recidivism and corrections spending." 27 Texas enacted these reentry policies and saved nearly $\$ 440$ million by January $2010 ; \$ 200$ million was then redirected to expand community corrections programs and treatment services. ${ }^{28}$

Facing similar upward projections in Indiana's prison population, the Indiana General Assembly passed House Enrolled Act 1006 ("HEA 1006") in 2013, which restructured the state's criminal code sentencing scheme. ${ }^{29}$ Overhauling the sentencing scheme was done to "give judges maximum discretion to impose sentences based on a consideration of all the circumstances related to the offense" 30 and to "maintain proportionality of penalties across the criminal code, with like sentences for like crimes." 31

Efforts to reduce the levels of mass incarceration at the federal level have shown that sentencing reform is only one of multiple factors necessary to produce positive results. ${ }^{32}$ Despite issuing some directives to local communities and providing minor additional funding, HEA 1006 did little with respect to reentryoriented policies. ${ }^{33}$ Indiana addressed some reentry-oriented policies in the past, but can still go further. ${ }^{34}$ This Note suggests that HEA 1006 focused on treating the symptom of prison overcrowding without treating the underlying ill: recidivism due to insubstantial reentry-oriented policies in Indiana.

Part I of this Note outlines what Indiana has done in the past two decades with respect to reentry-oriented reform, including the establishment of problemsolving courts and more defendant-friendly expungement laws. Part II delves into HEA 1006 and some of the more substantial changes it makes to the Indiana criminal code. Part III addresses the first proposal of this Note, wherein it outlines the inadequate funding mechanism of HEA 1006: a costly catch-22 for county leaders. ${ }^{35}$ Part IV focuses on three simple steps that the Indiana General Assembly can take to modernize Indiana's reentry-oriented policies.

27. Id. For purposes of this Note, justice reinvestment policies are the practical equivalent of evidence-based practices. See infra Part II.A (touching on evidence-based practices in HEA 1006).

28. Press Release, Council of State Gov'ts Justice Ctr., supra note 26.

29. See infra Part II.

30. IND. CODE § 35-32-1-1 (2014).

31. Id.

32. G. Roger Jarjoura et Al., Am. Inst. FOR Research, Assessing the LocAl Fiscal IMPACT OFHEA 10062 (2014), available at http://www.air.org/sites/default/files/downloads/report/ Assessing \%20the \%20Local\%20Fiscal\%20Impact $\% 20$ of $\% 20$ HEA $\% 201006$.pdf [http://perma.cc/7UXW-ARRV].

33. See infra Part II.

34. See infra Part I.

35. The Indiana legislature is addressing the funding mechanism in the First Regular Session of the 119th General Assembly (during the winter and spring of 2015). This Note will discuss the funding mechanism as originally passed and the two proposals introduced in the General Assembly in January 2015. 


\section{What INDiANa Has Done to B ATtLE RECIDIVISM THROUGH REENTRY POLICIES}

\section{A. Expungement}

Expungement laws are aimed at limiting the effect of collateral consequences: "statutory and/or regulatory disqualification[s] occurring in both the public and private sectors resulting from a criminal conviction." can take the form of employment disqualifications, prohibitions on seeking federal subsidies, and many other public and private ineligibilities due to a person's criminal history. ${ }^{37}$ According to Professor Michael Pinard, collateral consequences have never been as ubiquitous in American society as they are today. ${ }^{38}$ Indiana addressed this pervasive problem in 2013 and again in $2014 .{ }^{39}$

The original expungement law in Indiana was passed in $1983 .{ }^{40}$ From 1983 until 2009, the applicability of Indiana's expungement law was very narrow. ${ }^{41}$ Before the Indiana Supreme Court broadened its interpretation of the law in State ex rel. Indiana State Police v. Arnold ${ }^{42}$ in 2009 , the expungement statute was deemed to apply in only three circumstances: (1) if an individual was arrested but not charged; (2) if criminal charges were dropped; or (3) if the conviction to be expunged was for a minor traffic offense. ${ }^{43}$ In Arnold, the Indiana Supreme Court broadened a trial court's authority, giving judges the discretion to grant an expungement of records in the previously stated three circumstances and for individuals convicted of certain crimes that are more severe than minor traffic offenses. $^{44}$

In 2013, the Indiana General Assembly repealed the 1983 version of the law and replaced it with a newly refined expungement statute. ${ }^{45}$ Persons convicted of misdemeanors and felonies gained the statutory right to seek expungement. ${ }^{46}$ The law placed a restriction on misdemeanants: five years must pass between

36. Lahny R. Silva, Clean Slate: Expanding Expungements and Pardons for Non-Violent Federal Offenders, 79 U. CIN. L. REV. 155, 160 (2010).

37. Id. at 164 .

38. Michael Pinard, Reflections and Perspectives on Reentry and Collateral Consequences, 100 J. CRim. L. \& CRIMINOlogy 1213, 1214-15 (2010).

39. See infra notes 41-55 and accompanying text.

40. S.E.A. 295, 103rd Gen. Assemb., 1st Reg. Sess. (Ind. 1983).

41. See IND. CODE $§ 35-38-5-1$ (1983).

42. 906 N.E.2d 167 (Ind. 2009).

43. IND. CoDE $§ 35-38-5-1$ (1983).

44. See Jack Kenney, Traffic Stops, Expungement Statute, Other Holdings, Res Gest AE, Aug. 2009, at 42 ("Ind. Code $§ 35-38-5-1$ (d) gives the trial court almost unfettered discretion to grant or deny summarily a petition for expungement "without considering any statutory factors."') (quoting Arnold, 906 N.E.2d at 171).

45. IND. CODE $\S \S 35-38-9-1$ to -11 (2013).

46. Id. $\S \S 35-38-9-2$ to -3 . 
conviction and petition for expungement. ${ }^{47}$ Felons had a restriction placed at eight years. ${ }^{48}$ The 2013 version of the law mandated that the person seeking expungement could not have an existing or pending driver's license suspension and he or she had to complete his sentence successfully, including any term of supervised release. ${ }^{49}$ In 2014, the Indiana General Assembly struck these two statutory requirements and merely required that the person seeking expungement pay "all fines, fees and court costs, and satisf[y] any restitution obligation placed on the person as part of the sentence." 50

Both the 2013 and 2014 versions of the law, as opposed to the 1983 version, require a trial court to accept a petition for expungement if all the statutory requirements are satisfied. ${ }^{51}$ Other statutory safeguards against collateral consequences are found in Indiana Code section 35-38-9-10. ${ }^{52}$ For example, no person may discriminate against another person based upon an expunged criminal record; prohibited actions include the expulsion, suspension, refusal to employ, or refusal to grant or renew a license due to a criminal expungement. ${ }^{53}$ The law also safeguards other civil rights, such as "the right to vote, to hold public office, and to serve as a juror." 54

These newer Indiana expungement laws better address reentry-oriented policies that focus on lowering costs and recidivism. The need for such laws is reinforced by one study that found that prisoners who arranged for post-release employment had a "recidivism rate of $27.6 \%$ compared to $53.9 \%$ of those who did not." ${ }^{, 55}$ The statutory right to seek expungement will allow past offenders to find employment easier and, in turn, effectively reduce their recidivism rates.

\section{B. Problem-Solving Courts}

Problem-solving courts involve judges who participate throughout all aspects of a defendant's interaction with the criminal justice system, including treatment and post-release supervision - the main interaction of what some call reentry courts. ${ }^{56}$ Reentry courts provide inmates who are recently released from incarceration with a support system to hold themselves accountable and to help

47. Id.

48. Id. Those convicted of misdemeanors and felonies can seek expungement before the five and eight year requirements have been met; however, this is subject to the prosecutor's discretion. See id. § 35-38-9-2(b); see also id. § 35-38-9-3(c).

49. Id. § 35-38-9-2; id. § 35-38-9-3.

50. IND. CODE § 35-38-9-2(d)(3) (2014); id. § 35-38-9-3(e)(3).

51. See, e.g., id. §35-38-9-2(d) ("[T] he court shall order the conviction records described in subsection (b) expunged ....”) (emphasis added).

52. Id. § 35-38-9-10.

53. $I d$.

54. Id.

55. Silva, supra note 36 , at 162.

56. Randall T. Shepard, Elements of Modern Court Reform, 45 IND. L. REv. 897, 914 (2012). 
keep them from reoffending. ${ }^{57}$ It is hard to imagine, but some inmates reentering Indiana communities are pushed out the prison doors with a single pair of clothes and $\$ 75$ in their pocket. ${ }^{58}$

Problem-solving courts are tailored for each and every participant to ensure that they get the proper mental health, substance abuse, and other types of programming necessary for their successful reentry into society. ${ }^{59}$ Drug courts are another type of problem-solving court: courts that utilize alternative sentences and provide for intensive oversight, ending with a reward for successful completion, generally in the form of a graduation ceremony. ${ }^{60}$ Rewards may be given throughout the process, but participants likely have been given a second chance and will face punishment or incarceration for non-compliance.$^{61}$ In 1996, Barbara Brugnaux, a deputy prosecutor in Terra Haute, established the first drug court in Indiana and she continued to pilot the program as a trial court judge. ${ }^{62}$ Indiana's first and most distinguished reentry court was created by Judge John Surbeck in Allen County. ${ }^{63}$ His court sees national and international visitors regularly. ${ }^{64}$ Former Indiana Supreme Court Chief Justice Randall T. Shepard considers Judge Surbeck's reentry court to be the nation's leading problemsolving court. ${ }^{65}$

The Indiana Problem-Solving Courts Committee was established by the Indiana Judicial Conference in $2006 .^{66}$ The committee is "devoted to the integration of the problem-solving philosophy into the administration of justice. ${ }^{, 67}$ Additionally, the Indiana General Assembly passed a law in 2010 expanding the scope of problem-solving courts that the Indiana Judicial Center may certify. ${ }^{68}$ The law allows for the creation of additional types of problemsolving courts, such as those focused on domestic violence, mental health, and veterans' issues. ${ }^{69}$

A study done by NPC Research found that graduates from a select group of

57. Randall T. Shepard, Change in State Criminal Justice Policy: The Great Recession as a Catalyst for More Effective Sentencing, 23 FED. SENT. R. 146, 148 (2010).

58. Randall T. Shepard, Indiana's Place in American Court Reform: Rarely First, Occasionally Last, Frequently Early, Res Gestae, Mar. 2006, at 10.

59. Shepard, supra note 57, at 148.

60. Reentry Courts, CRIM. Just., Spring 2002, at 15.

61. Vera Inst. of Justice, Ctr. on Sentencing and Corr., The Potential of COMmunity CORRections to Improve SAFETy AND REDUCE INCARCERATION (2013), http://www.vera.org/sites/default/files/resources/downloads/potential-of-community-corrections.pdf [http://perma.cc/YL6Z-D88F].

62. Shepard, supra note 57, at 147.

63. Id. at 148.

64. Id.

65. Shepard, supra note 58, at 10.

66. Shepard, supra note 57, at 148.

67. Id. at 147.

68. H.E.A. 1271, 116th Gen. Assemb., 2d Reg. Sess. (Ind. 2010).

69. Elaine B. Brown, Smart on Crime, Res GeStAe, June 2012, at 49. 
drug courts in Indiana were three to four times less likely to reoffend than those who did not participate in the program; they estimated that cost-savings were upwards of $\$ 7$ million over a two-year period. ${ }^{70}$ Phrased differently, for every taxpayer dollar invested in the drug courts, there was a $\$ 5.37$ return. ${ }^{71}$ As of 2012 , Indiana had forty-nine certified drug courts, numerous reentry and veteran court options, and well over fifty court-administered drug and alcohol programs. ${ }^{72}$ Indiana is also home to the executive director of an organization for national drug court professionals: Karen Freeman-Wilson of Gary, Indiana. ${ }^{73}$ Indiana has become and remains a strong force at the front of the pack in problem-solving courts and the reduction of recidivism rates therefrom. ${ }^{74}$

\section{Council of State Governments Justice Center-Justice Reinvestment Plan}

In 2010, Governor Mitch Daniels and other Indiana government officials requested that the Council of State Governments Justice Center (CSG) and the Pew Center on the States (Pew Center) prepare strategies and proposals to deal with rising prison populations and increased spending on corrections. ${ }^{75} \mathrm{CSG}$ is a national non-profit organization that provides non-partisan, evidence-based advice to local, state, and federal government entities. ${ }^{76}$ The Pew Center is a nonprofit organization that "identifies and advances effective solutions to critical issues facing states ... [by applying] a rigorous, analytical approach." ${ }^{, 77}$ Between fiscal years 2000 and 2010, Indiana's IDOC population increased forty-seven percent to 28,389 inmates and IDOC funding increased by over $\$ 180$ million. $^{78}$

The four stated goals of the Justice Reinvestment plan were: (1) to increase public safety; (2) to reduce spending on corrections; (3) to ensure adequate prison capacity for serious and violent offenders; and (4) to hold offenders accountable for their crimes. ${ }^{79}$ None of the goals explicitly stated "to reduce prison population" or "to slow the rate of IDOC population growth," but the projections of a ballooning prison population and a $\$ 1.2$ billion estimated price tag for construction and operating costs were clearly the elephants in the room when deciding to reform the criminal justice system in Indiana. ${ }^{80}$

Much of the 2010 Justice Reinvestment program and its subsequent proposals

70. Id.

71. Shepard, supra note 56, at 915.

72. Id.

73. Shepard, supra note 58 , at 10.

74. See supra Part I.B.

75. Justice Reinvestment in Indiana, supra note 5.

76. Press Release, Council of State Gov'ts Justice Ctr., supra note 26.

77. Id.

78. Justice Reinvestment in Indiana, supra note 5.

79. Council of State Gov'ts Justice Ctr., Justice Reinvestment in Indiana: ANALYSES AND POLICY FRAMEWORK (2010), available at http://csgjusticecenter.org/wpcontent/uploads/2012/12/CCEC_Presentation_12-16.FINAL_.pdf [http://perma.cc/GT6S-59NQ].

80. Justice Reinvestment in Indiana, supra note 5. 
became the framework for HEA $1006 .{ }^{81}$ For instance, sentence proportionality for drug crimes was discussed thoroughly in the program's Analysis and Policy Framework. ${ }^{82}$ CSG intimated that Indiana's sentencing policy for the low-level sale of cocaine was "among the most severe and costly." grams of cocaine, Indiana's pre-HEA 1006 sentencing structure called for twenty to fifty years of incarceration. ${ }^{84}$ For a comparable offense, Texas provided for a range of two to twenty years, Wisconsin's sentencing structure called for up to twelve and a half years, and Ohio's maximum sentence was a single year ${ }^{85} \mathrm{HEA}$ 1006 changed this disproportionality to fall in line with other states; the crime now carries a possible punishment of two to twelve years. ${ }^{86}$

Other proposals from CSG and the Pew Center undergirded the HEA 1006 changes in Indiana criminal law. ${ }^{87}$ Those proposals called for giving "judges more options when sentencing non-violent offenders ...., [to] use community corrections for felony offenders ... [and to] incentivize local governments to reduce [Level 6] felony admissions to prisons." ${ }^{, 88}$ These changes will be touched on in the next Part of this Note.

Some of the Justice Reinvestment proposals did not make it into the changes made by HEA $1006 .{ }^{89}$ One such proposal, applying swift and certain sanctions for probation violations, is the foundation of my proposal discussed in Part Four. ${ }^{90}$ A handful of necessary changes went missing from both the Justice Reinvestment plan and HEA $1006 .{ }^{91}$ One such change is the needed expansion of therapeutic reentry programs at the IDOC. One in particular, called Purposeful Incarceration, will be discussed in Part Four. ${ }^{92}$

81. Compare Council of State Gov'ts Justice Ctr., supra note 79, at 10, with Ind. Code § 35-32-1-1 (2014).

82. See generally Council of State Gov'ts Justice Ctr., supra note 79.

83. Id. at 12 .

84. Id.

85. Id.

86. IND. CODE $§ 35-50-2-5.5$ (2014).

87. Compare Council of StATE Gov'Ts Justice CTR., supra note 79, at 10, with Ind. Code $\S 35-32-1-1$ (2014).

88. Compare Council of STATE Gov'Ts Justice CTR., supra note 79, at 10, with Ind. Code $\S 35-32-1-1$ (outlining the general purposes of HEA 1006) and infra Part II.C (regarding the housing of Level 6 felons in county jails).

89. Compare Council of State Gov'Ts Justice CTR., supra note 79, at 10, with Ind. Code $\S 35-32-1-1$.

90. See infra Part IV.C.

91. See infra Part IV.C.

92. See infra Part IV.A. 


\section{HOUSE ENROLLED ACT $1006^{93}$}

Indiana restructured its criminal code in 2013 for the first time since $1977 .{ }^{94}$ Among other things, the sentencing structure was overhauled. ${ }^{95}$ For example, any felony committed prior to July 1, 2014 was classified as either Murder or a Class A, B, C, or D felony. ${ }^{96}$ Any felony committed after July 1, 2014 falls into a classification of either Murder or a Level 1, 2, 3, 4, 5 or 6 felony. ${ }^{97}$ Table 1 in the Appendix shows the differences between the sentence classifications and sentence lengths before and after the passage of HEA 1006.

Part of the theory behind the revision of the sentencing structure was to divert non-violent offenders away from prisons, keeping scarce prison space available for sex and violent offenders. ${ }^{98}$ Other reasons for the change are spelled out in Indiana Code section 35-32-1-1, such as sentence proportionality ${ }^{99}$ and the promotion of evidenced-based practices for the rehabilitation of offenders in a community setting. ${ }^{100}$

This Part of the Note discusses some of the more prominent features of the new law and some of the debated effects of its passage. Section A discusses what evidence-based practices are and how the General Assembly is incentivizing their use. Section B touches on different substantive changes in HEA 1006 and the debated effect those changes will have on the IDOC prison population. Finally, Section C will discuss the housing of Level 6 felons in local county jails.

\section{A. Evidence-Based Practices}

Evidence-based practices are policies utilized by criminal justice agencies that are demonstrated and reinforced by research and proven to reduce offender

93. H.E.A. 1006, 118th Gen. Assemb., 2d Reg. Tech. Sess. (Ind. 2014). House Enrolled Act 1006 (HEA 1006) was originally passed during the 2013 First Regular Session of the 118th Indiana General Assembly. However, the Indiana General Assembly convened at the end of the Second Regular Session (what is called the Second Regular Technical Session) to amend HEA 1006. Any mention of HEA 1006 in the Note is to this finalized technical corrections bill, which went into effect on July 1, 2014.

94. See generally William A. Kerr, Foreword: Indiana's Bicentennial Criminal Code, 10 IND. L. REv. 1 (1976) (providing a survey of substantive and procedural changes in Indiana's last criminal code revision prior to HEA 1006).

95. See infra notes $96-98$ and accompanying text.

96. IND. CODE $\$ \S 35-50-2-3$ to -7 (2013).

97. IND. CODE $\S \S 35-50-2-3$ to -7 (2014).

98. Id. § 35-32-1-1.

99. See infra notes 120-26 and accompanying text (regarding the changes in sentencing for drug dealing offenses); see also COUNCIL OF STATE GOV'TS JusticE CTR., supra note 79 (providing comparative information for drug offense sentences in multiple states and finding that Indiana had a severe lack of proportionality and graduated sentences for certain drug crimes). This report came in 2010 when Governor Daniels asked the Council of State Governments Justice Center to assist Indiana in coming up with a Justice Reinvestment plan. See supra Part I.C.

100. IND. CODE $§ 35-32-1-1$. 
recidivism. ${ }^{101}$ One of the general purposes of HEA 1006 was to promote the use of evidence-based practices in local community corrections programs. ${ }^{102} \mathrm{In}$ incentivizing that goal, the Indiana General Assembly tied state funding for probation services to the "development and use of evidence-based services, programs, and practices that reduce probationers' risk for recidivism." 103

Generally, utilizing evidence-based practices includes the establishment of performance measurements, the intensive collection of data, and the modification of policies and practices pursuant to the analysis of the data collected. ${ }^{104}$ The use of evidence-based practices will force counties to focus on reducing recidivism rates; however, adequate funding is a necessary component to the introduction of these policies. ${ }^{105}$ Some experts deem a lack of resources among the top problems related to inadequate reentry policies. ${ }^{106}$ Due to the increased data collection and analysis that occurs with the use of evidence-based practices, probation officers will likely have a lower average caseload. ${ }^{107}$ As will be discussed in Part Three, this lower caseload per officer compounds the costly catch-22 that local county officials are facing due to what they consider to be the unfunded mandate titled HEA $1006 .^{108}$

\section{B. IDOC Prison Population Predictions}

Numerous reports (from a number of agencies) provide for markedly different predictions regarding changes in the IDOC prison population due to the code revisions in HEA 1006. ${ }^{109}$ This is a particularly relevant issue because HEA 1006 was prompted mainly by rising prison populations ${ }^{110}$ and ultimately by the

101. Roger K. Warren, Evidence-Based Practices and State Sentencing Policy: Ten Policy Initiatives to Reduce Recidivism, 82 IND. L.J. 1307, 1308 (2007).

102. IND. CODE $\S 35-32-1-1(5)$.

103. IND. CODE $\S \S 11-13-2-2$ to -3 (2014).

104. Nat'l Inst. of Corr., A Framework for Evidence-Based Decision Making in LOCAL CRIMINAL JuSTICE SYSTEMS 28 (2010), available at http://cepp.com/documents/EBDM\%20 Framework.pdf [http://perma.cc/UV6A-PEJD].

105. See Faye S. Taxman et al., From Prison Safety to Public Safety: Innovations in Offender Reentry 6 (Oct. 10, 2002) (unpublished report) (on file with the U.S. Dep't of Justice).

106. Id.

107. Interview with Ralph Watson and Madonna Wagoner, Directors, respectively, Hamilton Cnty. Cmty. Corr. and Prob., in Noblesville, Ind. (Sep. 19, 2014) [hereinafter Watson \& Wagoner Interview].

108. See JARJOURA ET AL., supra note 32, at 88 (stating that all Indiana probation jurisdictions contacted were at capacity and that all jurisdictions generally considered HEA 1006 to be an unfunded mandate).

109. See infra notes $110-13$ and accompanying text.

110. See Council of State Gov'ts Justice CTR., supra note 79 (indicating that two of the four goals in the 2010 Justice Reinvestment proposal were "to reduce spending on corrections" and to "[e]nsure adequate capacity for incarcerating serious and violent offenders"); see also Marilyn Odendahl, Concerns Exist Over Proposed Sentencing Bill, Ind. LAW. (Jan. 1, 2014) 
extremely high costs of building new prison facilities. ${ }^{11}$ Applied Research Services Inc., an Atlanta-based company, projected an increase of 6000 inmates by $2024 .{ }^{112}$ The Department of Correction predicts the population will increase by 2000 inmates in that same time frame. ${ }^{113}$ The Indiana Legislative Services Agency, the non-partisan fiscal analysis and research wing of the General Assembly, estimates that the population will decrease by 1200 to 1600 inmates. ${ }^{114}$

With an eye toward yearly fluctuations in prisoner population, a study done by the American Institutes for Research (AIR) estimated that up to 14,000 offenders could be diverted away from the IDOC and into local community corrections programs on an annual basis. ${ }^{115}$ This prediction is commensurate with the legislature's stated goal of using evidence-based practices to treat "offenders in a community setting." 116 The CSG's Justice Center agrees with this approach because "research shows that pairing effective supervision and quality treatment in the community have a significant impact on recidivism reduction." 117 The AIR study further estimated that it will cost $\$ 10.5$ million dollars each year to fund the services required to serve those offenders at the local level. ${ }^{118}$

Rep. Greg Steuerwald, the author of HEA 1006, emphasized that due to the legislative "goal . . . to deal with low-level nonviolent offenders in a different manner," he believes that HEA 1006 will lead to a decrease in the IDOC population. ${ }^{119}$ Important to this legislative goal was the policy decision that most offenders arrested for drug crimes after the passage of HEA 1006 would be treated as low-level nonviolent offenders. ${ }^{120}$ This is apparent in the vast differences between penalties for drug dealing offenses pre code-revision and

http://www.theindianalawyer.com/article/print?articleId=33131 [http://perma.cc/E4SU-8DHG] (discussing the belief that the IDOC will reach capacity at 30,000 inmates); JOSH SPEAR, IND. DeP'T OF Corr., OfFender Population Statistical Report (2014), available at http://www.in.gov/idoc/2376.htm [http://perma.cc/GP4-WEMC] (providing that total adult population in the IDOC as of September 1, 2014 was 29,155, merely three percent below operational bed capacity); IND. CODE § 35-32-1-1(6) (2014) (stating "the use of scarce prison space. ...") (emphasis added).

111. See Justice Reinvestment in Indiana, supra note 5.

112. Marilyn Odendahl, Criminal Code Overhaul Shifts Focus to Sentencing, IND.LAw. (Dec. 18, 2013), http://www.theindianalawyer.com/article/print?articleId=33041 [http://perma.cc/GK6CQGMZ].

113. Id.

114. Id.

115. JARJOURA ET AL., supra note 32, at 2.

116. IND. CODE $§ 35-32-1-1(5)$ (2014) (emphasis added).

117. Grasso E-mail Interview, supra note 11.

118. JARJOURA ET AL., supra note 32, at 2.

119. Odendahl, supra note 112.

120. Compare IND. CoDE $\S \S 35-48-4-1$ to -4 (2014), with IND. CoDE $\S \S 35-48-4-1$ to -4 (2012) (regarding the different classifications in drug dealings offenses pre-code-revision and post-coderevision). 
penalties for drug dealing offenses post code-revision. ${ }^{121}$ For example, what previously would have been a Class A Felony dealing in cocaine ${ }^{122}$ is now a Level 4 Felony dealing in cocaine. ${ }^{123}$ The hypothetical Class A Felony dealer, who committed the offense of dealing in three grams of cocaine prior to July 1, 2014, would have faced a possible prison sentence of twenty to fifty years. ${ }^{124}$ His Level 4 Felony counterpart, committing the same offense of dealing in three grams of cocaine after July 1, 2014, would face a possible prison sentence of two to twelve years. ${ }^{125}$ There was even a more severe reduction in penalties for certain drug possession crimes. ${ }^{126}$

On the other side of the prison population debate, the IDOC--along with others--predicts an increase in IDOC inmates. ${ }^{127}$ This prediction is due, in large part, to the changes made to the truth-in-sentencing statute in HEA $1006 .{ }^{128}$ The truth-in-sentencing statute provides for a system of giving prisoners credit time tow ard their sentences for good behavior while they are incarcerated. ${ }^{129}$ For local county inmates or IDOC prisoners who committed crimes before July 1, 2014, those with good behavior would receive "[one] day of credit time for each day [they are] imprisoned for a crime or confined awaiting trial or sentencing." ${ }^{130}$ Put differently, this meant that an inmate would serve only half of the sentence he or she received. ${ }^{131}$

Aside from Level 6 felons, who continue to receive fifty-percent credit, those who commit a felony after July 1, 2014 will only receive one day of credit for every three days served. ${ }^{132}$ This means that these offenders will now serve

121. Compare IND. CoDE $§ \S 35-48-4-1$ to -4 (2014), with IND. CODE $§ \S 35-48-4-1$ to -4 (2012) (regarding the different classifications in drug dealings offenses pre-code-revision and post-coderevision).

122. IND. CODE $§ 35-48-4-1$ (2012). The time spent in prison for the advisory sentence (had the inmate achieved maximum good-time credit) would have been fifteen years. $I d$. $\S \S 35-50-6-3$, -4. Table 2 in the Appendix compares the differences between the old and new advisory sentences.

123. IND. CODE $§ 35-48-4-1$ (c)(1) (2014). The time spent in prison for the advisory sentence under the new scheme (if the inmate achieves maximum good-time credit) would be four and a half years. Id. $\S \S 35-50-6-3,-4$.

124. IND. CODE $\S 35-50-2-4$ (2012).

125. IND. CODE $§ 35-50-2-5.5$ (2014).

126. Compare IND. CoDE $\S \S 35-48-4-6$ to -11 (2014), with IND. CoDE $\S \S 35-48-4-6$ to -11 (2012) (regarding the different classifications in drug possession offenses pre code-revision and post code-revision).

127. See supra note 112 and accompanying text (regarding the IDOC's prediction of an increase in 2000 IDOC inmates by the year 2024).

128. IND. CODE $§ 35-50-6-3.1$ (2014).

129. See generally id. $\S \S 35-50-6-1$ to -8 .

130. Id. § 35-50-6-3. Different classifications exist for inmates who do not exhibit good behavior during incarceration; however, this Note only touches on credit time for inmates with good behavior.

131. See id.

132. Id. $\S 35-50-6-3.1$. 
seventy-five percent of their sentence. Randy Koester, Deputy Commissioner of Reentry for the Department of Correction, believes that this will cause an increase in prisoners: "[IDOC prisoners'] length of stay is really what drives how many prison beds we need and how many prison facilities we need. . . And those length[s] of stays, if they get adjusted upwards, eventually . . . creates a stacking effect and we need to create new capacity, new prisons." ${ }^{133}$ Table 3 in the Appendix outlines the new truth-in-sentencing scheme and how it will affect the minimum, advisory, and maximum sentences for all felonies.

This Note does not take part in the prison population-prediction debate; rather, it proposes that if the prison population ends up increasing, no cost savings will be passed on to the counties due to the inadequate funding mechanism in HEA 1006 (as originally passed). ${ }^{134}$ If the prison population decreases, the offenders will likely be treated in local community corrections programs or held in county jails that lack the funding and resources to deal with them properly. ${ }^{135}$

\section{Housing Level 6 Felons in County Jails}

Prior to HEA 1006, Class D (now Level 6) felons would often be sent to an IDOC facility instead of being housed locally in county jails. ${ }^{136}$ Roughly 10,000 Class D felons a year were sent to an IDOC facility. ${ }^{137}$ A controversial addition to HEA 1006 is codified in Indiana Code section 35-38-3-3. ${ }^{138}$ Between June 30, 2014 and January 1, 2016, all Level 6 felons who will be released within ninetyone days or less may not be sent to the IDOC. ${ }^{139}$ A change made during the 2015 legislative session states that, minus a few exceptions, no Level 6 felons may be housed in the IDOC beginning January 1, 2016. ${ }^{140}$ Therefore, if a defendant convicted of a Level 6 felony in 2016 stays in jail six months prior to sentencing and is sentenced to the maximum two and a half years, he or she will be required to stay in the local county jail. ${ }^{141}$

Hamilton County Jail Commander Jason Sloderbeck estimates that by July 1, 2016, the Hamilton County jail inmate population will have increased by at least 80 inmates, which would place the jail twenty-five percent above

133. Odendahl, supra note 110.

134. See infra Part III (regarding the costly impact of HEA 1006 for local communities).

135. See infra Part III.

136. See generally Reducing Recidivism and Sentencing Reform Before the Criminal Law and Sentencing Pol'y Study Comm., 118th Gen. Assemb., Interim Sess. 127 (2013), available at http://www.in.gov/legislative/interim/committee/minutes/CLSPG9Q.pdf [http://perma.cc/BB3TLD5P] (Exhibit 9, Indiana Prosecuting Attorneys Council presentation).

137. Id.

138. IND. CODE $\S 35-38-3-3$ (2014).

139. Id. (stating that the earliest possible release date is measured from the date of sentencing).

140. H.E.A. 1006, 119th Gen. Assemb., 1st Reg. Sess. (Ind. 2015) (discussing P.L. 179-2015 at page 1978).

141. See Ind. CodE $\S 35-38-3-3(d)$. 
operational capacity. ${ }^{142}$ Because this issue was anticipated, the Indiana General Assembly has agreed to allocate a per diem reimbursement for every Level 6 felon housed in county jails. ${ }^{143}$ Any additional costs determined to be medically necessary by the county sheriff will also be allocated. ${ }^{144}$ Sloderbeck considers this redirection of offenders fair: local counties can rightfully be required to treat and house their own criminals. ${ }^{145}$ However, some consider the per diem funding insubstantial compared to the estimated fifty-five dollar daily cost of housing inmates at an IDOC facility. ${ }^{146}$

Although only thirty-two percent of Indiana county jails were considered overcrowded when the Indiana General Assembly was debating HEA 1006, half of them operated with more than eighty-five percent of their beds filled. ${ }^{147}$ However, these numbers may not accurately reflect the current capacity of all Indiana jails. ${ }^{148}$ When the AIR study was conducted, the Hamilton County jail could hold 296 inmates. ${ }^{149}$ However, the county has been operating at over ninety percent capacity for the last several years and was officially overcapacity with more than 300 inmates as of October 21, 2014. ${ }^{150}$

According to the AIR study, only twenty-four percent of Indiana county jails have enough capacity for the impact of HEA $1006 .{ }^{151}$ Even for those counties that operate below 100 percent capacity, Sloderbeck considers running a jail at eighty to ninety percent capacity a "serious problem." 152 This is because a jail's operational bed capacity does not always reflect the actual number of beds available for use. ${ }^{153}$ Classifying prisoners by security risk or special needs may leave some portions of prison facilities dormant. ${ }^{154}$ Not only does operating at or above capacity strain the staff and local resources, but it potentially opens the county up to liability for overcrowding, mainly for instances of high-security-risk inmates injuring others. ${ }^{155} \mathrm{~W}$ ith half of Indiana jails understaffed, more funding is needed at the local level. ${ }^{156}$ Part Three discusses this inadequate funding and the need for the Indiana General Assembly to up its ante.

142. Sloderbeck Interview, supra note 4.

143. IND. CODE $\S 35-38-3-3(\mathrm{e})$.

144. Id.

145. Sloderbeck Interview, supra note 4.

146. Id.

147. JARJOURA ET AL., supra note 32, at 72.

148. Sloderbeck Interview, supra note 4.

149. JARJOURA ET AL., supra note 32, at 69.

150. Id. Operating above capacity costs Hamilton County a per-inmate fee on their health-care services contract.

151. Id. at 72 .

152. Sloderbeck Interview, supra note 4.

153. $I d$.

154. $I d$.

155. Id.

156. See infra Part III. 


\section{The COSTLY CATCH-22}

As originally passed, the funding mechanism of HEA 1006 was highly inadequate, as outlined below in Section A. The Indiana General Assembly proposed two alternative bills that would alter the funding mechanism, discussed below in Sections B and C.

\section{A. HEA 1006 Funding}

A report from the IDOC indicated that $\$ 36,087,332$ in grants was appropriated to seventy-one local jurisdictions' community corrections programs in fiscal year 2014. ${ }^{157}$ HEA 1006 did not alter this yearly state funding for local programs. ${ }^{158}$ The applicable statute on additional funding for the criminal code revisions in HEA 1006 is Indiana Code section 11-12-2-1. ${ }^{159}$ The legislature capped the amount of additional grants or appropriations it will give to local counties at $\$ 11$ million per year. ${ }^{160}$ Section 11-12-2-1(b) states:

Before March 1 of each year, the department shall estimate the amount of any operational cost savings that will be realized in the state fiscal year ending June 30, from a reduction in the number of individuals who are in the custody or made a ward of the department of correction that is attributable to the sentencing changes made in [HEA 1006]. ${ }^{161}$

If the estimation of the IDOC is true and the number of offenders in the prison system increases (even if only for a couple of years), it seems the additional funding will be non-existent. It appears the funding would be capped by the amount of savings realized due to a lower number of offenders in the state's custody due to the sentencing changes. Under the IDOC's prediction of prison population growth, no additional grant money would be available to the counties to offset any preparations they undertook for the purported increase in offenders. ${ }^{162}$ Even if the IDOC population does decrease initially, the statute requires that the funding hinge upon the fact that the decrease in offenders is attributable to the sentencing changes made in HEA $1006 .{ }^{163}$ It is anyone's guess how this standard will be applied.

This Note presents a skeptical view that: (1) the General Assembly did not

157. See Ind. Dep't of Corr., Grant Allocation to Local Jurisdictions for Fiscal YEARS 2014 \& 2015 (2015) (on file with author).

158. Id.

159. IND. CODE $§ 11-12-2-1$ (2014).

160. Id.

161. H.E.A. 1006, 119th Gen. Assemb., 1st Reg. Sess. (Ind. 2015) (outlining the changes made to Indiana Code section 11-12-2-1 in P.L. 179-2015 at page 1957).

162. The Indiana Legislative Services Agency predicted that the inmate population would decrease by 1200 to 1600 individuals by 2025; the AIR thought that 14,000 offenders could be diverted away from the prison system on a yearly basis. See supra notes 110-14 and accompanying text.

163. IND. CODE $§ 11-12-2-1(b)$ (2014). 
have access to any reliable information regarding operational cost savings attributable to HEA 1006 on or before March 1, 2015; (2) any reduction in the number of individuals in the custody of the IDOC will not be because of the changes in HEA 1006; and (3) any operational cost savings will be well below the $\$ 11$ million dollar cap on additional funding. This is a costly catch-22 for local county leaders.

According to a report prepared by the IDOC, $\$ 87$ million was spent in fiscal year 2013 on community corrections programs in the state of Indiana. ${ }^{164}$ The seventy-one local jurisdictions receiving state grants got a total of about $\$ 36$ million from the IDOC during fiscal year 2013; defendant user fees and county matching dollars--called "project incomes"--accounted for the other $\$ 51$ million. ${ }^{165}$ According to the directors of the Hamilton County Probation and Community Corrections, Madonna Wagoner and Ralph Watson, local programs rarely obtain 100 percent of their defendant user fees. ${ }^{166}$ Not only does Hamilton County match state funding (approximately thirty-percent per year), but Hamilton County receives only an estimated sixty-five to seventy-five percent of defendant user fees that are due; this leaves the local taxpayers to run the programs at a deficit. ${ }^{167}$ It does not help that most probation departments in the state believe they spend more money attempting to collect defendant user fees than they actually recover. ${ }^{168}$

Hypothetically, if Hamilton County is successful in collecting seventy-five percent of defendant user fees, there is still over $\$ 550,000$ that needs to be accounted for. ${ }^{169}$ Assuming that all counties in Indiana match thirty-percent of their IDOC funding and that they successfully collect seventy-five percent of user fees that are due, taxpayers across the state already foot a deficit of millions of dollars for uncollected "project incomes". ${ }^{170}$ If this Note continues to assume that the same percentages apply throughout Indiana, Bartholomew County is under budget by roughly $\$ 500,000$ and Elkhart County is under budget by nearly $\$ 865,000$. $^{17}$

Luckily for Hamilton County, it is the richest county in the state ${ }^{172}$ and one of the most affluent in the country. ${ }^{173}$ Ralph Watson and Madonna Wagoner are

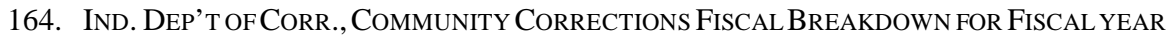
2013 (2013) (on file with author).

165. $I d$.

166. Watson \& Wagoner Interview, supra note 107.

167. Id.

168. JARJOURA ET AL., supra note 32, at 89.

169. See InD. DEP'T OF CORR., supra note 157.

170. Id.

171. Id.

172. Morton J. Marcus, The Rich Stay Rich Among Indiana's Counties, Ind. Bus. ReV., Fall 2000, available at http://www.ibrc.indiana.edu/ibr/2000/fall00/01.pdf [http://perma.cc/6LQQTU7S].

173. Hamilton County Among Nation's Wealthiest, 13 WTHR INDIANAPOLIs, http://www.wthr. com/story/5345140/hamilton-county-among-nations-wealthiest [http://perma.cc/2KJF-LXNL]; 
not only worried about how Hamilton County will handle the impact of HEA 1006; they are just as worried about the community corrections and probation programs in jurisdictions that are not as financially stable. ${ }^{174}$ On top of these financial troubles, the counties that have not already implemented evidence-based practices will have probation and community corrections officers with necessarily smaller caseloads and a funding mechanism that requires the use of such evidence-based practices. ${ }^{175}$

Local community corrections and probation leaders do have some options. The responsibility of complying with the directives of HEA 1006 is necessary until the Indiana General Assembly addresses some of the issues this Note outlines. Local officials should categorize all offenders based upon their risk of reoffending. Those who commit misdemeanor offenses with a small chance of recidivating should use a call-in service instead of more formal probation supervision. Evidence-based practices and the data collected therefrom led Hamilton County to implement this system ${ }^{176}$ in lieu of ordinary probation supervision; it has been positively viewed by some in the county. ${ }^{177}$ Lower recidivism rates are expected because the "assignment to programs or interventions where a need has not been identified ... may have no benefit and, in fact, [may] elicit the opposite effect being sought" for those categorized as low risk reoffenders. ${ }^{178}$ The advent of the call-in system also resulted in an increase in the collection of user fees from those participating in the program. ${ }^{179}$ The Georgia Department of Corrections instituted a similar system and found that "more resources and time [have been given] to its high-risk probationers, thereby increasing public safety and improving supervision quality." 180

One specific example of the costly catch-22 is found in Howard County. In fiscal year 2013, the county received a state grant for upwards of $\$ 450,000$, with a project income totaling over $\$ 570,000 .{ }^{181}$ According to a story by Martin Slager of The Kokomo Times, Howard County faces some tough financial decisions. ${ }^{182}$

Census Expected to Show Hamilton County Tops in Coveted Demographics, InDianaPolis Bus. J., http://www.ibj.com/articles/16395-census-expected-to-show-hamilton-county-tops-in-coveteddemographics [http://perma.cc/5G8A-XUUR].

174. Watson \& Wagoner Interview, supra note 107.

175. Id.; see IND. CODE $§ 11-12-2-4(\mathrm{~b})(8)$ (2014) (requiring a plan of collaboration between probation and community corrections to include evidence-based services for felony offenders and documentary evidence of compliance with certain rules).

176. See generally Call-in Supervision, Gov'T OF Hamilton CounTy., Ind., http://www. hamiltoncounty.in.gov/topic/subtopic.php?topicid=557\&structureid=25 [http://perma.cc/7RHR7FQ8] (last visited July 20, 2015) (discussing the call-in service, an alternative for probation supervision).

177. Watson \& Wagoner Interview, supra note 107.

178. Wilkinson, supra note 18 , at 618.

179. Watson \& Wagoner Interview, supra note 107.

180. VERA InST. OF JuSTICE, supra note 61, at 17.

181. IND. DEP'T OF CORR., supra note 157.

182. Martin Slager, County Work Release Program Still Elusive, Кокомо TRIв. (July 20, 
A study done to seek new space for a work release facility estimated that clean-up and restoration costs for one venue would have cost the county $\$ 3.1$ million. ${ }^{183}$ Furthermore, the change in law regarding the housing of Level 6 felons locally means that 113 of the 197 inmates in the Howard County jail (as of June 2014) would have been diverted away from the IDOC had their cases been filed after July $1,2014 .{ }^{184}$ These 113 hypothetical inmates would then need to be housed and treated locally, straining the entire criminal justice system in Howard County.

Hypothetically, in the best case scenario, the General Assembly determined on or before March 1, 2015 that the operational cost savings realized due to the sentencing changes in HEA 1006 exceeded the eleven million dollar cap found in Indiana Code section 11-12-2-1(b)(4). If the eleven million dollars were then distributed equally among the local jurisdictions already receiving state grants, any county could expect an additional $\$ 155,000$ in state funding for the next fiscal year. ${ }^{185}$ According to Ms. Wagoner, that would support only three additional probation officers in her jurisdiction. ${ }^{186}$ These additional resources are less valuable in counties that not already utilizing evidence-based practices due to the probable decreased caseload per probation officer. ${ }^{187}$ The utility of that $\$ 155,000$ is even further depressed because the Indiana General Assembly disallowed use of such funding to renovate county jails or to construct work release facilities that are attached to county jails. ${ }^{188}$ As originally passed, HEA 1006's funding mechanism is completely insufficient; the Indiana General Assembly needs to provide more funding to local jurisdictions for the establishment and upkeep of successful community corrections and probation programs.

\section{B. 2015 Senate Bill 464}

Although S.B. 464 is a mental health and drug bill that began in the Committee on Health \& Provider Services, it strips the inadequate funding mechanism from HEA 1006. ${ }^{189}$ S.B. 464 leaves Indiana Code section 11-12-21 (a) untouched, providing that, "for the purpose of encouraging counties to develop . . . alternatives to imprisonment at the state level, the commissioner shall, out of funds appropriated for such purposes, make grants to counties for the establishment and operation of community corrections programs." ${ }^{190}$ This option may seem desirable at first, mainly because S.B. 464 would uncap the $\$ 11$ million

2014, 2:58 AM), http://www.kokomotribune.com/news/local_news/article_77a8c11e-f27d-5c9eb4c2-35d07c3c42dc.html [http://perma.cc/6RUA-25KU].

183. Id.

184. Id.

185. IND. CODE § 11-12-2-1(b)(4) (2014).

186. Watson \& Wagoner Interview, supra note 107.

187. Id.

188. IND. CODE $§ 11-12-2-8$ (2014).

189. Id.

190. See id.; see also IND. CODE § 11-12-2-1 (2014). 
in appropriations and would untie appropriation amounts from the amount realized due to a lower number of offenders in the IDOC as of March 1, 2015. This essentially nullifies the costly catch-22 discussed above. However, providing no explicit amount of funding may be risky in a budget year. S.B. 464's changes to the HEA 1006 funding mechanism is even less desirable when compared to the proposal put forth in 2015 House Bill 1006 (now HEA 1006-2015), which is discussed below.

\section{HEA 1006-2015}

Authored and co-authored by the same group of legislators as the original HEA 1006, HEA 1006-2015, or 2015 House Bill 1006 (“H.B. 1006-2015"), originally provided the adequate funding where HEA 1006 fell short. ${ }^{191}$ It was short-titled as "Criminal justice funding" and provided some additional depth in a new chapter titled, "Justice Reinvestment Community Grants Program."192 Now, the statute is titled "Justice Reinvestment Advisory Council." And although that chapter remained relatively the same as it passed through the budgeting process, the General Assembly dropped the ball yet again when it failed to provide any substantial money to fund the program.

Throughout H.B. 1006-2015, the new law has replaced the language previously referring to the IDOC with the Indiana Judicial Center. ${ }^{193}$ The Indiana Judicial Center will likewise administer the new chapter on the justice reinvestment advisory council. ${ }^{194}$ The goal of the program, as initially written, was to develop alternatives to incarceration across the state, mainly in the underfunded jurisdictions that are not as financially stable as Hamilton County. ${ }^{195}$ The operative section of the proposed new chapter states:

(b) The Indiana Judicial Center shall award grants: (1) to assist with the establishment and maintenance of community corrections programs in each county by 2020 , including community corrections programs serving multiple counties; (2) to assist communities and counties to develop and maintain alternatives to incarceration that are needed in the applicable community or county; and (3) to reduce recidivism. ${ }^{196}$

This language did not find its way into the final bill. The funding originally provided for in H.B. 1006-2015 appropriated \$30 million in fiscal year 2015 and $\$ 50$ million in fiscal year $2016 .{ }^{197}$ However, in the 2015 budgeting process, the

191. Compare H.B. 1006, 119th Gen. Assemb., 1st Reg. Sess. (Ind. 2015), with H.E.A. 1006, 118th Gen. Assemb., 2d Reg. Tech. Sess. (Ind. 2014). Greg Steuerwald authored the bill and the enrolled act, both of which Jud McMillan, Matt Pierce, and Linda Lawson co-authored.

192. H.B.1006, 119th Gen. Assemb., 1st Reg. Sess. (Ind. 2015).

193. See generally id.

194. Id.

195. Id.

196. Id.

197. H.B. 1001, proposed Amendment \#1, 119th Gen. Assemb., 1st Reg. Sess. (Ind. 2015), 
bill was stripped of nearly all of this proposed funding. The new law provides that "the expenses of the advisory council shall be paid by the Indiana judicial center from funds appropriated to the Indiana judicial center for the administrative costs of the justice reinvestment advisory council." ${ }^{, 198}$ According to the budget passed in 2015 , the judicial center was allocated merely $\$ 5.4$ million for fiscal year 2015-2016. ${ }^{199}$

The original opponents to HEA 1006 thought the bill was too soft crime; this led many to hold up the passage of the law because there was "no political will to spend the money." ${ }^{200}$ Further, HEA 1006 proceeded to pass in 2013 only upon a last minute budget deal containing $\$ 6.4$ million to help local jurisdictions absorb the costs of the changes made. ${ }^{201}$ This appropriation was far short of the $\$ 30$ million originally requested by the bill's authors. ${ }^{202}$ All told, the now-nominal funding of $\$ 5.4$ million for FY 2015-2016 is almost laughable.

\section{WHERE ELSE Did HEA 1006 FALL SHORT?}

More defendant friendly expungement laws, the widespread use of problemsolving courts, and the Justice Reinvestment plan of 2010 have helped Indiana catch-up in the criminal justice reform movement. These efforts have focused on establishing reentry-oriented policies and reducing recidivism, but they have been piece-meal and insufficient. ${ }^{203}$ Reentry policies continue to be reactive and fragmented across most jurisdictions. ${ }^{204}$ Likewise, Indiana's approach to HEA 1006 was highly reactive in the sense that it was prison overcrowding that prompted the legislative response. ${ }^{205}$ The reevaluation of reentry programs was

available at http://www.indianahouserepublicans.com/clientuploads/PDF/AM100101.pdf [http:// perma.cc/M4PP-ZAPF].

198. H.E.A. 1006, 119th Gen. Assemb., 1st Reg. Sess. (Ind. 2015) (codified as Indiana Code section 33-38-9.5-2(f) (2015)).

199. H.E.A. 1001, 119th Gen. Assemb., 1st Reg. Sess. (Ind. 2015) (found at page 2665).

200. Maureen Hayden, Criminal Code Reform Stalls Over Funding, Howey PoL. (Apr. 23, 2013, 5:49 AM), http://howeypolitics.com/Content/Columns/Maureen-Hayden/Article/MaureenHayden-Criminal-code-reform-stalls-over-funding/10/302/8696 [http://perma.cc/6EBA-AJSR].

201. Maureen Hayden, Criminal Code Reform Advances Without Much Funding, HowEY POL. (Apr. 26, 2013, 4:42 AM), http://howeypolitics.com/Content/Columns/Maureen-Hayden/Article/ Maureen-Hayden-Criminal-code-reform-advances-without-much-funding/10/302/8710 [http://perma.cc/ND9T-YLKJ].

202. Id.

203. See Brown, supra note 69, at 51 ("Despite [efforts on problem-solving courts], it remains clear that a comprehensive solution lies with the legislature. . . [I]t's time we are all 'smart on crime."”).

204. Pinard, supra note 21 , at 104.

205. See Council of State Gov'ts Justice CtR., supra note 79 (comparing prison population changes in several states, with Indiana at a forty-one percent increase between 2000 and 2008; Wisconsin, Ohio, Missouri, Michigan and Illinois were all below a thirteen percent increase in that same period of time); see also JARJOURA ET AL., supra note 32, at 4-5 (citing rising prison 
not even considered in this landmark shift in Indiana criminal justice policy. ${ }^{206}$ HEA 1006 was the perfect vehicle to overhaul reentry policy in Indiana to battle prison population growth and recidivism effectively, but the Indiana General Assembly fell short by focusing much too narrowly on sentence reform and prison overcrowding.

This Part of the Note will discuss what HEA 1006 did not include and how to best address reentry reform going forward. Section A will propose the expansion of therapeutic communities within the IDOC. Section B advances the idea that risk and needs assessments should be used during all critical stages in the criminal justice process. Section $\mathrm{C}$ urges the Indiana General Assembly to quicken its pace in providing for the implementation of a uniform schedule of sanctions for community corrections and probation violations.

\section{A. The Necessity of Expanding the Availability of Therapeutic Communities Within the IDOC}

Many agree that communities need successful reentry programs that can be administered after release from prison. ${ }^{207}$ However, some commentators also agree that the most sophisticated (and possibly the most successful) reentry programs are those that begin at the outset of the inmate's period of incarceration: this is considered the "institutional phase" of reentry. ${ }^{208}$ Additionally, a "major preliminary obstacle [to inadequate reentry policies] is insufficient availability and varying quality of prison programs." ${ }^{209}$ Although HEA 1006 provided for the use of evidence-based practices in community corrections to reduce recidivism, the reduction of recidivism may very well hinge upon numerous aspects of correctional programming. ${ }^{210}$

The IDOC has a multitude of programming opportunities for those housed at a state prison facility. ${ }^{211}$ This section's proposal may seem at odds with the wide array of choices inmates have upon entering an IDOC facility; ${ }^{212}$ however, the

populations as a driving force behind the criminal code revisions in HEA 1006).

206. See infra Part IV.A.

207. See Jessica A. Focht-Perlberg, Two Sides of One Coin - Repairing the Harm and Reducing Recidivism: A Case for Restorative Justice in Reentry in Minnesota and Beyond, 31 HAMline J. Pub. L. \& PoL'y 219, 242-43 (2009); see generally Taxman et al., supra note 105, at 4; Grasso E-mail Interview, supra note 11 ("Research shows that pairing effective supervision and quality treatment in the community have a significant impact on recidivism reduction ....").

208. Taxman et al., supra note 105, at 10; see Focht-Perlberg, supra note 207, at 243 (citing Joan Petersilia, What Works in Prisoner Reentry? Reviewing and Questioning the Evidence, 68 Fed. РRob. 4, 5-7 (2004)).

209. Focht-Perlberg, supra note 207, at 244.

210. Joan Petersilia, What Works in Prisoner Reentry? Reviewing and Questioning the Evidence, 68 Fed. Probation 4, 5-6 (2004).

211. See generally Programs, IND. DEP'T OF CORR., http://www.in.gov/idoc/2799.htm [http://perma.cc/B6NB-6A3Z] (last visited Jan. 1, 2015).

212. Id. (providing a list of twenty-two programs available at IDOC facilities). 
reduced recidivism rates for those participating in an IDOC therapeutic community may alone justify the need to expand the availability of these programs. ${ }^{213}$ Therapeutic communities ("TCs") are "specialized intensive [programs] designed to treat offenders with severe drug addictions" and have cut the recidivism rates for participants in half; TC participants' rates for poor conduct are also only one-tenth that of the general population inmates. ${ }^{214}$

One specific TC program is called Purposeful Incarceration, which is a collaborative initiative between the Indiana courts system and the IDOC: a judge will sentence a "chemically addicted offender" to one of the five IDOC therapeutic community locations throughout the state. ${ }^{215}$ In return, the judge will consider a sentence modification upon the defendant's successful completion of the program. ${ }^{216}$ The IDOC currently has about $1800 \mathrm{TC}$ beds in five of its correctional facilities. ${ }^{217}$ Intensive oversight and treatment (twelve to fifteen hours daily) is provided while in the program, which is generally a minimum of eight months long. ${ }^{218}$ Upon completion, the offender will likely receive treatment through a reentry court, community work release, or other community corrections program. ${ }^{219}$

The Indiana General Assembly could focus their efforts on expanding the available beds for IDOC therapeutic communities; the legislature could also collaborate with the IDOC to provide sufficient resources so that the Purposeful Incarceration program would not be limited to a minimum of eight months. ${ }^{220}$ Jerry Vance, the IDOC Director of Programming, touched on this issue, stating that "some sentences are too short to allow for treatment [in prison]. . .",21 Expanding the Purpose Incarceration program to individuals with an earliest possible release date of less than eight months can significantly increase the amount of inmates who can benefit from a therapeutic community setting. Additionally, expanding the definition of those who qualify for Purposeful Incarceration from "a chemically addicted offender" to something more general may capture less severe drug addicts and drug abusers. Expanding the number of beds and the overall availability of therapeutic communities may help reduce

213. $I d$.

214. Id.; Purposeful Incarceration, IND. DEP'T OF CORR., http://www.in.gov/idoc/2798.htm [http://perma.cc/U9ZP-YHS7] (last visited Jan. 1, 2015).

215. $I d$.

216. Id.

217. Ind. Criminal Justice Ass'n, 'Purposeful InCARCeration': A Partnership Between the Department of CORRECTIONS AND THE COURTS, http://www.indiana correctionalassociation.org/Professional/Purposeful_Incarceration.pdf [http://perma.cc/PG962TJH].

218. Meeting Minutes: Hearing on Recidivism and Sentencing Reform Before the Criminal Law and Sentencing Policy Study Committee, 118th Gen. Assemb., Interim Sess. 116 (Ind. 2013) [hereinafter Meeting Minutes].

219. Ind. CRIMINAL JUSTICE Ass'N, supra note 217.

220. Meeting Minutes, supra note 218.

221. Id. 
recidivism in a larger subset of IDOC prisoners reentering local Indiana communities.

\section{B. Providing for the Use of Risk Assessments throughout All Stages of the Criminal Justice System}

Risk assessments "measure the probability that a person will reoffend if or when released into the community."222 Assessments will provide an individualized analysis of each offender's criminogenic traits, such as anti-social behavior, low-levels of education and employment, and mental health or substance abuse issues. ${ }^{223}$ Generally, the higher the risk of reoffending, the higher the level of supervision suggested ${ }^{224}$ this is because there is a general understanding that offenders with a low risk of reoffending need less monitoring to reduce recidivism in that population. ${ }^{225}$ Instead of targeting nonviolent offenders as a policy decision based on the type of offense, a more narrowed, case-by-case analysis would likely produce better results in lowering recidivism rates. $^{226}$

Ohio instituted its own reentry reform in the early 2000s with part of its focus on needs and risk assessment for every offender entering an Ohio correctional facility. ${ }^{227}$ A comprehensive evaluation of each offender is undertaken at the time of admission. ${ }^{228}$ This risk and needs assessment results in a personalized "reentry accountability plan." 229 In Indiana, a similar risk assessment system ${ }^{230}$ is used by

222. VERA InST. OF JUSTICE, supra note 61, at 16.

223. Id. at $16,26$.

224. See, e.g., id. at 16-17.

225. See Taxman et al., supra note 105, at 20 ("While providing services to violent or chronic offenders often involve political risks, the biggest gains in public safety and cost savings are achieved when resources are targeted to exactly these kind of offenders."); James M. Byrne \& Faye S. Taxman, Targeting for Reentry: Inclusion/Exclusion Criteria across Eight Model Programs, 68 Fed. Probation 53 (2004); see also Wilkinson, supra note 18, at 618 ("At the same time, assignment to programs or interventions where a need has not been identified or is inappropriate may have no benefit and, in fact, elicit the opposite effect being sought.").

226. See IND. CoDE $§ 35-32-1-1(6)$ (2014) (stating that the statute should be "construed in accordance with its general purposes to ... keep dangerous offenders in prison by avoiding the use of scarce prison space for nonviolent offenders" ) (emphasis added).

227. NAncy G. Vigne et AL., Urban Inst., A Portrait OF Prisoner ReEntry in OHIO 45-46

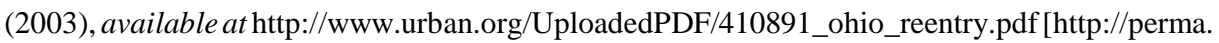
cc/96SG-K8WL].

228. $I d$.

229. Reginald A. Wilkinson et Al., Ohio Dep't of Rehab. And Corr., The Ohio Plan for Productive OfFENdER REENTRy AND ReCidivism REDUCTION 5 (2002), available at http://www.drc.state.oh.us/web/ohio\%20plan\%20final1.pdf [http://perma.cc/F33L-NNCX].

230. See generally Michelle Goodman \& Lisa Thompson, Indiana's New Risk Assessment Tools: What You Should Know, IND. Ст. TIMES (Apr. 13, 2011), http://indianacourts.us/times/ 2011/04/risk-assessment/ [http://perma.cc/M24A-9NA3]. 
probation officers in creating a Presentence Investigation (PSI) report. ${ }^{231}$ A PSI report is generally required in all felony cases. ${ }^{232}$ However, that report is solely used by the sentencing judge in choosing an appropriate sentence in light of the offender's risk and needs assessment. ${ }^{233}$ If Indiana were to follow Ohio's lead, the PSI report could be the document utilized in all stages of the criminal justice process. Not only could it be used by judges and prosecutors in determining the best possible sentence, it could help target ${ }^{234}$ the right offenders for the correct reentry programming once incarcerated. It could further be utilized in key decision points, like community intervention decisions, violation response decisions, and discharge determinations. ${ }^{235}$

The use of Indiana's already existent PSI report to assess needs and risks for reentry programming would provide a more narrowed, case-by-case analysis without the need for additional resources. ${ }^{236}$ Further, with serious felons now serving seventy-five percent of their sentences, ${ }^{237}$ the expansion of centrally administered programming (such as Purposeful Incarceration) is all the more important. ${ }^{238}$ A recent study done by the National Reentry Resource Center found that six of eight states effectively reduced their recidivism rates through reentry policies that emphasized risk and needs assessment throughout the whole criminal justice process. ${ }^{239}$ Indiana would do well by following in their footsteps. The Indiana General Assembly should expand IDOC programming and expand risk and needs assessments by directing use of the PSI report throughout all key decision points in the criminal justice process.

231. Presentence Investigation Report Application, IND. JuD. BRANCH, http://www.in.gov/ judiciary/jtac/2932.htm [http://perma.cc/XJY9-US6E] (last visited Oct. 9, 2014); see IND. CoDE $§$ 11-13-1-8(b)(4) (2014) (giving the Judicial Conference of Indiana's Board of Directors the authority to proscribe minimum standards for PSI reports).

232. IND. CODE $\S 35-38-1-8$ (2014).

233. Presentence Investigation Report Application, supra note 231.

234. Discussions on offender "targeting" is a necessary topic with regard to programming and offender reentry policy. However, a more in-depth discussion is better suited for after the Indiana General Assembly takes on a more holistic approach to reduce recidivism. Such an approach includes changes like those proposed in Part IV.A-C.

235. NAT'L Inst. OF CORR., supra note 104.

236. Some minimal resources would be expended in the additional use of the PSI report; however, no additional resources would be needed in the sense that the assessment system is already in place and a PSI report is already prepared in almost all felony cases. Simply utilizing the already prepared PSI to help determine placement in a community correction program after release or to help determine a sanction for violations of probation will not cost the state taxpayers any extra money.

237. IND. CoDE $§ 35-50-6-3.1$ (2014).

238. See supra Part IV.B.

239. See generally Council of State Gov'ts Justice Ctr., Reducing Recidivism, supra note 22 . 


\section{The Propriety of a Uniform and Set Schedule of Sanctions for Community Corrections and Probation Violations}

In 2012, the Indiana General Assembly amended Indiana Code section 11-131-8 to require the board of directors of the Indiana Judicial Conference (IJC) to adopt rules prescribing minimum standards concerning a "schedule of progressive probation incentives and violation sanctions, including judicial review procedures." ${ }^{240}$ The law went into effect July 1, 2012, but the IJC has yet to institute such a schedule of incentives and sanctions. ${ }^{241}$ The IJC adopted its yearly Probation Standards on March 7, 2014; the standards made no mention of the probation incentives and sanctions schedule. ${ }^{242}$ A meeting of the Problem-Solving Courts Committee of the IJC later that month suggested that a pilot program of the new graduated sanctions started early 2014 and will be followed by a second pilot program. ${ }^{243}$ No date is set for a prescribed set of rules. ${ }^{244}$

A uniform and set schedule of sanctions is paramount in reevaluating revocation procedures to comply with Dr. Roger Jarjoura's directive to fight the "urge" to revoke for every violation of probation. ${ }^{245}$ This so-called directive was to combat the realities of probation and parole revocations in Indiana: sixty-two percent of probation and forty-eight percent of parole technical violations resulted in the offender returning to a state prison facility. ${ }^{246}$ Technical violations are considered violations of any term of probation or community corrections placement that is not an arrest for the commission of a new crime. ${ }^{247} \mathrm{~W}$ ith the IJC not taking control and with nearly 100 different probation jurisdictions in Indiana, the Indiana General Assembly needs to provide more guidance on the issue. The Indiana General Assembly could codify the schedule of sanctions itself or urge the IJC to quicken its pace.

North Carolina implemented graduated sanction options in 2011 due to similar concerns in rising prison populations. ${ }^{248}$ Not only did North Carolina reduce its prison admission rate by twenty-one percent within three years ${ }^{249}$ it

240. H.E.A. 1200, 117th Gen. Assemb., 2d Reg. Sess. (Ind. 2012).

241. See generally Ind. Jud. CTR., Indiana Probation Standards (2014), available at http://www.in.gov/judiciary/probation/files/prob-standards-standards.pdf [http://perma.cc/HD8F$\mathrm{XC} 4 \mathrm{H}]$.

242. $I d$.

243. Ind. Judicial Ctr., Problem-Solving Courts Committee Meeting 2 (2014), available at $\mathrm{http}: / / \mathrm{www}$. in.gov/judiciary/center/files/prob-solv-cts-minutes-2014.pdf[http://perma. cc/FF7E-GWKV].

244. Id.

245. JARJOURA ET AL., supra note 32, at 2.

246. Id. at 5 .

247. See id. at 11.

248. Erik Eckholm, A State Cuts Jail Time for Probation Violators, and Costs, N.Y. TimES, Sep. 12, 2014, at A14, available at http://www.nytimes.com/2014/09/12/us/north-carolina-cuts-jailtime-for-probation-violators-and-costs.html?_r=0 [http://perma.cc/G56W-PSAY].

249. $I d$. 
also reduced its overall probation population by 5000 offenders and had 10,000 less technical revocations within two years of the law's passage. ${ }^{250}$ Other states have enacted similar legislation, with Hawaii at the forefront by providing for "swift and certain" sanctions, including local jail stays, for probation violations. ${ }^{251}$

This Note does not distinguish between technical violations and violations for a new arrest because downplaying technical violations--especially failed or missed drug tests--is highly inappropriate when a main component of reentry programming is substance abuse treatment for drug offenders and addicts. ${ }^{252} \mathrm{~A}$ study done by the Department of Justice found that sixty-eight percent of criminals in 2002 met the criteria for substance dependence or abuse within the year before their arrest. ${ }^{253}$ The importance of disregarding the distinction between technical and new-crime revocations is even more revealing when coupled with the statistic that those classified as substance dependents or abusers are twice as likely to have three or more probation or prison sentences. ${ }^{254}$

The Indiana General Assembly or the IJC might take a different view when determining the progressive schedule of probation sanctions; however, it is imperative that the probation officers of Indiana get on the same page for the upcoming years. It would behoove the Indiana General Assembly to codify the scheduled sanctions before the implementation of HEA 1006 is fully complete, or in the alternative, to pressure the IJC to get on with it.

\section{CONCLUSION}

States across the country are seeing rising prison populations and increased spending due to a prolonged culture of being "tough on crime." ${ }^{\text {. } 55}$ With billion dollar estimates for the expansion of correctional facilities, states are beginning to reevaluate criminal justice policy through the help of non-profits and other professional organizations. ${ }^{256}$ The focus on reentry-oriented policies has come to the forefront since the effort to better understand the issue was articulated by Attorney General Janet Reno during the 1990s and later by President George W.

250. See Council of State Gov'ts Justice CtR., Reducing Recidivism, supra note 22, at 9.

251. Vera InSt. OF Justice, supra note 61 (including Arkansas, Kentucky, Maryland and Vermont, which provide for swift and certain sanctions to lower the amount of revocations directly to prison).

252. See generally JeNNifer R. KARBERG \& Doris J. JAMES, U.S. DeP'T OF JUSTICE, BuREAU of Justice Statistics, Substance DePendence, Abuse, and Treatment of Jail InMATEs, 2002 (2005), available at http://www.bjs.gov/content/pub/pdf/sdatji02.pdf [http://perma.cc/KA8UHQS6].

253. $I d$.

254. $I d$.

255. See generally Adam M. Gershowitz, An Informational Approach to the Mass Imprisonment Problem, 40 ARIz. ST. L.J. 47, 47-55 (2008).

256. Justice Reinvestment in Indiana, supra note 5; Press Release, Council of State Gov'ts Justice Ctr., supra note 26. 
Bush in 2004..$^{257}$

What followed was a trend of reentry reform efforts among the states to reduce recidivism by dealing with offenders in a different manner. ${ }^{258}$ Indiana had produced some reentry-oriented statutes and programs throughout the 2000s; however, those efforts were fragmented and insufficient. ${ }^{259}$ Similarly, the passage of HEA 1006 was not focused on reentry and its underlying rationale; it merely represented a change in policy to slow the growth of the IDOC prison population and to prolong funding the very costly expansion of IDOC facilities. HEA 1006 was a landmark shift in Indiana criminal justice policy that failed to institute reentry reform in the state adequately. This Note proposes three simple changes the Indiana General Assembly can make to modernize reentry policies in Indiana; the fourth and final proposal is for a sufficient funding mechanism to allow for local jurisdictions to provide adequate evidence-based practices and community corrections alternatives. Whether that funding comes from a new bill in the next legislative session or from a special appropriation between now and then, the Indiana General Assembly simply needs to fork over the money.

257. Travis, supra note 19 , at 84 .

258. Id. at 85 .

259. See supra Part I. 
APPENDIX

Table 1: Crime Classifications and Sentence Lengths

\begin{tabular}{|c|c|c|c|c|}
\hline & Class & Pre-HEA 1006 & Level & $\begin{array}{c}\text { HEA-1006 } \\
\text { Sentencing } \\
\text { Scheme }\end{array}$ \\
\hline $\begin{array}{l}\text { IND. CODE } \\
\S 35-50-2-3\end{array}$ & Murder & 45-65 years & Murder & 45-65 years \\
\hline $\begin{array}{l}\text { IND. CODE } \\
\S 35-50-2-4\end{array}$ & A & 20-50 years & 1 & 20-40 years \\
\hline $\begin{array}{l}\text { IND. CODE } \\
\S 35-50-2-4.5\end{array}$ & & & 2 & 10-30 years \\
\hline $\begin{array}{l}\text { IND. CODE } \\
\S 35-50-2-5\end{array}$ & B & $6-20$ years & 3 & $3-16$ years \\
\hline $\begin{array}{l}\text { IND. CODE } \\
\S 35-50-2-5.5\end{array}$ & & & 4 & $2-12$ years \\
\hline $\begin{array}{l}\text { IND. CODE } \\
\S 35-50-2-6\end{array}$ & $\mathrm{C}$ & $2-8$ years & 5 & $1-6$ years \\
\hline $\begin{array}{l}\text { IND. CODE } \\
\S 35-50-2-7\end{array}$ & $\mathrm{D}$ & $0.5-3$ years & 6 & $0.5-2.5$ years \\
\hline
\end{tabular}


Table 2: Advisory Sentence Lengths

\begin{tabular}{|c|c|c|c|c|}
\hline & Class & $\begin{array}{c}\text { Pre-HEA } \\
1006\end{array}$ & Level & $\begin{array}{c}\text { HEA-1006 } \\
\text { Sentencing Scheme }\end{array}$ \\
\hline $\begin{array}{l}\text { IND. CODE } \\
\S 35-50-2-3\end{array}$ & Murder & 55 years & Murder & 55 years \\
\hline $\begin{array}{l}\text { IND. CODE } \\
\S 35-50-2-4\end{array}$ & A & 30 years & 1 & 30 years \\
\hline $\begin{array}{l}\text { IND. CODE } \\
\S 35-50-2-4.5\end{array}$ & & & 2 & 17.5 years \\
\hline $\begin{array}{l}\text { IND. CODE } \\
\S 35-50-2-5\end{array}$ & B & 10 years & 3 & 9 years \\
\hline $\begin{array}{l}\text { IND. CODE } \\
\S 35-50-2-5.5\end{array}$ & & & 4 & 6 years \\
\hline $\begin{array}{l}\text { IND. CODE } \\
\S 35-50-2-6\end{array}$ & $\mathrm{C}$ & 4 years & 5 & 3 years \\
\hline $\begin{array}{l}\text { IND. CODE } \\
\S 35-50-2-7\end{array}$ & $\mathrm{D}$ & 1.5 years & 6 & 1 years \\
\hline
\end{tabular}


Table 3: Truth-in-Sentencing-Credit Time

\begin{tabular}{|c|c|c|c|}
\hline Level & Minimum & Advisory & Maximum \\
\hline Murder & $45(33.75)$ & $55(41.25)$ & $65(48.75)$ \\
\hline Level 1 & $20(15)$ & $30(22.5)$ & $40(30)$ \\
\hline Level 2 & $10(7.5)$ & $17.5(13)$ & $30(22.5)$ \\
\hline Level 3 & $3(2.5)$ & $9(6.75)$ & $16(12)$ \\
\hline Level4 & $2(1.5)$ & $6(4.5)$ & $12(9)$ \\
\hline Level 5 & $1(0.75)$ & $3(2.25)$ & $6(4.5)$ \\
\hline Level 6 & $0.5(0.25)^{*}$ & $1(0.50)^{*}$ & $2.5(1.25)^{*}$ \\
\hline \multicolumn{4}{|c|}{$* 50 \%$ credit time } \\
\hline
\end{tabular}

